\title{
Planned home birth assistance: challenges during the COVID-19 pandemic
}

\author{
Assistência ao parto domiciliar planejado: desafios enfrentados durante a pandemia da COVID-19 \\ Atención al parto domiciliario planeado: desafíos enfrentados durante la pandemia de la Covid-19
}

$\begin{array}{r}\text { Natália Webler' } \\ \text { ORCID: 0000-0003-4215-3526 } \\ \text { Lilian Conceição Guimarães de Almeida' } \\ \text { ORCID: 0000-0001-6940-9187 } \\ \text { Jordana Brock Carneiro' } \\ \text { ORCID: 0000-0002-7496-852X } \\ \text { Luana Moura Campos' } \\ \text { ORCID: 0000-0001-5671-1977 } \\ \text { Tanila Amorim Glaeser' } \\ \text { ORCID: 0000-0002-0487-6013 } \\ \text { Margarete Costa Santos' } \\ \text { ORCID: 0000-0002-5067-5263 } \\ \text { Telmara Menezes Couto' } \\ \text { ORCID: 0000-0001-6836-8563 } \\ \hline\end{array}$

'Universidade Federal da Bahia. Salvador, Bahia, Brazil. "SobreParto - Coletivo de Assistência ao Parto de Salvador. Salvador, Bahia, Brazil.

How to cite this article: Webler N, Almeida LCG, Carneiro JB, Campos LM, Glaeser TA, Santos MC, et al. Planned home birth assistance: challenges during the COVID-19 pandemic. Rev Bras Enferm. 2022;75(Suppl 1):e20210083. https://doi.org/10.1590/0034-7167-2021-0083

\section{Corresponding author:}

Natália Webler

E-mail:n1006w@gmail.com

EDITOR IN CHIEF: Dulce Barbosa ASSOCIATE EDITOR: Ana Fátima Fernandes

Submission: 02-24-2021

Approval: 06-27-2021

\section{ABSTRACT}

Objective: To understand the challenges faced by urban midwives in assisting planned home births during the COVID-19 pandemic. Methods: Qualitative study, based on the Collective Subject Discourse methodological framework, carried out with eight professionals, members of a birth care collective from the northeast region of Brazil. Data was collected between September and October of 2020 using the focus group technique. Results: The collective discourses revealed five central ideas: Changing assistance strategy; Dealing with frustration; Facing the fear of contamination; Avoiding exposure to the virus; and Keeping distance during the care process. Final considerations: The challenging condition the pandemic brings to the care of planned home births is made evident, being marked by the need for collective protection and the pressure of following health recommendations. The study also points out the need for official protocols and good quality information based on scientific evidence and humanizing principles to guide health care.

Descriptors: Home Childbirth; Pandemics; COVID-19; Health Personnel; Midwifery.

\section{RESUMO}

Objetivo: Conhecer os desafios enfrentados por parteiras urbanas para a assistência ao parto domiciliar planejado durante a pandemia da COVID-19. Métodos: Estudo qualitativo, ancorado no referencial metodológico do Discurso do Sujeito Coletivo, realizado com oito profissionais integrantes de um coletivo de assistência ao parto, no Nordeste brasileiro. Os dados foram coletados entre setembro e outubro de 2020 mediante a técnica de grupo focal. Resultados: Os discursos coletivos revelaram cinco ideias centrais: Alterar a condução da assistência; Lidar com as frustrações; Encarar o medo da contaminação; Evitar a exposição ao vírus; e Manter-se distanciada durante a assistência. Considerações finais: Evidencia-se um contexto pandêmico desafiador para assistência ao parto domiciliar planejado, marcado pela necessidade de proteção coletiva e por angústias advindas do atendimento às recomendações sanitárias. O estudo sinaliza, ainda, a relevância de protocolos oficiais e informações de qualidade que norteiem um atendimento pautado em evidências científicas e na humanização.

Descritores: Parto Domiciliar; Pandemias; Infecções por Coronavírus; Pessoal de Saúde; Parteira.

\section{RESUMEN}

Objetivo: Conocer los desafíos enfrentados por parteras urbanas para la atención al parto domiciliario planeado durante la pandemia de COVID-19. Métodos: Estudio cualitativo, ancorado en el referencial metodológico del Discurso del Sujeto Colectivo, realizado con ocho profesionales integrantes de un colectivo de atención al parto, en Nordeste brasileño. Datos fueron recolectados entre septiembre y octubre de 2020 mediante técnica de grupo focal. Resultados: Discursos colectivos revelaron cinco ideales centrales: Alterar la conducción de la atención; Lidiar con las frustraciones; Encarar el miedo a contaminación; Evitar la exposición al virus; y Mantenerse distanciada durante la atención. Consideraciones finales: Evidencia un contexto pandémico desafiador para atención al parto domiciliario planeado, marcado por la necesidad de protección colectiva y angustias advenidas de la atención a recomendaciones sanitarias. El estudio señaliza, aún, la relevancia de protocolos oficiales e informaciones de calidad que dirija a una atención pautada en evidencias científicas y en la humanización. Descriptores: Parto Domiciliario; Pandemias; Infecciones por Coronavirus; Personal de Salud; Partería. 


\section{INTRODUCTION}

Specialized care for planned home births (PHB), despite being a viable possibility and a growing trend for childbirths in Brazil, is still an alternative available only to a few women in the country. In general, this possibility is restricted to families with greater income, who can afford a private care team ${ }^{(1)}$. In the context of Brazilian public health care, only one maternity hospital has implemented this type of care (in 2013), revealing that public administration's interest in developing policies to make this option accessible through SUS (Sistema Único de Saúde) - The Brazillian unified health care system -, is still incipient ${ }^{(2)}$. This situation contrasts with the scenario found in the Netherlands and the United Kingdom, places with high rates of home births and considered worldwide as a role model for obstetrical care ${ }^{(3-4)}$.

Concerning this matter, the Ministry of Health's (MH) positioning is questionable, while demonstrating faint support for PHB through SUS and briefly addressing the practice in official documents. The documents mention the roles of doctors, nurses, and midwives in this care context and advises that women who choose this type of childbirth should not be discouraged, however, without bringing up the benefits and the importance of standardizing this modality of out-of-hospital care ${ }^{(5)}$.

Alongside the lack of public policies, the Professional Councils show no interest in regulating and encouraging PHB care, not having established specific guidelines and protocols so far. Physicians are discouraged by these entities from providing this type of assistance, if not prohibited entirely ${ }^{(6-7)}$. This position is anchored on the allegation of increased risk in the home environment, reinforcing the hospital-centric culture around the event of birth ${ }^{(8)}$. On the other hand, it is possible to glimpse the evolution of this practice when performed by nurses, supported, in general, by technical notes and opinions provided by the nursery councils ${ }^{(9-12)}$.

This reality demands - from professionals working in PHB -, midwives, nurses, and obstetricians - who commonly call themselves "urban midwives" - the development of care routines of their own, to make sure women at home receive proper attention during pregnancy and after giving birth. In general, this leads to the adaptation of the hospital care model to the home environment, prioritizing humanized birth practices and avoiding invasive, unnecessary interventions ${ }^{(12-13)}$. This context contributes to the greater physical and personal closeness between the professional and the mother, which helps her to take the role of the protagonist of the birth and favors a more welcoming practice ${ }^{(14)}$.

However, the COVID-19 pandemic pressed the need for adaptation in professional practices to deal with the risk of contamination. International studies show the high transmissibility and potential lethality of the disease, especially in health professionals, and the fact that it could also lead to dangerous complications for the mother and the fetus ${ }^{(15-16)}$. In the Brazilian scenario, data on maternal morbidity and mortality due to the disease is alarming, resulting in the epidemiological bulletin issued by the $\mathrm{MH}$ classifying pregnant and recently pregnant women as groups of high risk for COVID-19 (16-18). $^{\text {. }}$

In this sense, the non-regulation of the PHB care practice proves to be an even more complex problem, given the need to structure new protocols that prioritize the safety of the family and the health care team. Thus, it is vital to understand how professional midwives carry out home birth care in a pandemic context, which can benefit the development of adaptation strategies for this care model.

\section{OBJECTIVE}

To understand the challenges faced by urban midwives in assisting planned home births during the COVID-19 pandemic.

\section{METHODS}

\section{Ethical aspects}

This work was approved by the Research Ethics Committee of the Escola de Enfermagem da Universidade Federal da Bahia (UFBA) [Federal University of Bahia's Nursing School]. The participants signed the Informed Consent Form being aware of the objectives, risks, and benefits of the research. It should also be noted that they were informed that the speeches would be recorded (using portable devices) and the transcription documents would be virtually archived for a period of five years. Finally, in order to preserve the anonymity of the participants, their names were replaced by a code composed by the letter $\mathrm{E}$ or $\mathrm{M}$, referring to the professional classes "nurse" or "doctor", respectively, followed by a randomly chosen Arabic numeral for each participant (e.g. $E 1, M 1, E 2, M 2)$.

\section{Study type}

Qualitative research guided by the Consolidated criteria for reporting qualitative research (COREQ) tool and based on the Collective Subject Discourse (CSD) methodological framework, designed by Lefèvre and Lefèvre ${ }^{(19)}$. This method is based on the premises of the Social Representation Theory: it enables the grouping of different speeches, that is, socio-cognitive structures representing key expressions, on which a collective thought is built to reveal the Central Idea Synthesis (CIS), the essential content ${ }^{(19-20)}$.

\section{Study scenario}

The study scenario was a collective provider of humanized childbirth care in a capital located in the Northeast region of Brazil. The group is formed by nurses and obstetricians, selfstyled "urban midwives". The term "collective" is due to the work philosophy that these professionals follow, whose characteristics and principles are based, above all, on the transdisciplinarity and horizontality of the care they provide.

\section{Data source}

For inclusion in the research, it was established as a criterion to be a health professional member of the midwifery group active in the PHB scenario. However, participants on maternity leave or vacations were not included.

The study population selection was deliberately done by the researchers, by invitation through telephone calls. In total, eight 
female health care professionals, aged between 30 and 61 years, took part in the research, including four doctors and four nurses, all specialists in the obstetric area. Their experience in PHB care varied between 6 months and 30 years.

\section{Data collection, organization, and analysis}

To carry out the data collection, which took place between September and October of 2020, the researchers approached the participants in advance by attending the weekly meetings of the urban midwives team (nurses and obstetricians), which takes place virtually through the Google Meet platform. This online tool was also used to collect the speeches. The first stage of data collection comprised individual meetings between the researchers and each of the research participants, with an average duration of 35 minutes, in which questions from a premade questionnaire were asked to conduct the socio-demographic and professional characterization of the group.

After this step, there was a collective meeting between all midwives and researchers in the form of a Focus Group (FG). Through this strategy, after the researchers asked the questions, the collaborators were able to interact and dialogue with each other, sharing their experiences, exposing their opinions, raising discussions, and provoking reflections regarding the PHB care provided by the urban midwives during the pandemic ${ }^{(21)}$. Prior to the start of the FG, which lasted 40 minutes, the professionals agreed to participate in an "icebreaker" moment, in which they took turns to introduce themselves and took part in group-dynamic activities. This contributed to making them feel welcomed and safe to talk about their personal experiences during the FG.

To conduct this collective experience in an organized and productive way, the researchers employed a semi-structured questionnaire with open questions based on a defined guiding question: "Tell me about the PHB care you provide during the COVID-19 pandemic".

To meet the methodological rigor requirements of the study, the criteria established by COREQ guided the methodological trajectory of the investigation closely. The data collection was carried out by the researchers responsible for this paper, who had previous experience in conducting this type of investigation. Later, in possession of the FG recordings, the participants' speeches were transcribed in full by a nursing student trained to perform such activity. Then, the transcript was examined by two postgraduate students who took part in this paper to ensure the interview contents were preserved. Finally, the transcribed document was sent back to the collaborators of the study in its entirety for them to read and confirm that their speeches were faithfully registered.

Once the collection process came to completion, the data was systematized based on the methodological premises of the CSD. At first, the speeches were grouped according to the key expression they presented, making possible the emergence of $\mathrm{CIS}$ around the speeches produced in first person singular and that showed a collective representation of the theme ${ }^{(19-20)}$ (Chart 1). These patterns were analyzed, interpreted, and discussed based on the framework of current scientific literature on home birth, humanized obstetric care, and COVID-19.
Chart 1 - Central Ideas Synthesis of urban midwives' discourses on the challenges in assisting planned home births during the COVID-19 pandemic

\begin{tabular}{|c|c|}
\hline Numbering & Central Idea Synthesis \\
\hline 01 & 1A - Changing assistance strategy \\
\hline 02 & 1B - Dealing with frustration \\
\hline 03 & 1C - Facing the fear of contamination \\
\hline 04 & 1D - Avoiding exposure to the virus \\
\hline 05 & 1E - Keeping distance during the care process \\
\hline
\end{tabular}

\section{RESULTS}

The collective discourses of the professionals highlighted the main challenges faced in PHB care during the pandemic period, represented by the five central ideas below.

\section{SCI $1 \mathrm{~A}$ - Changing assistance strategy}

The discourse points to repeated changes in assistance strategies by urban midwives as one of the challenges faced in the pandemic period. Consequently, the participants exposed the alterations made to prenatal care and team behavior during home labor care.

At the beginning of the pandemic, there was a lot of information, and it all changed daily. It took a while to establish a basic protocol for care, based on the positive experiences shared by professionals from various states. It was necessary to stop using the bathtub, even though there was no scientific consensus if it increased the risk of contamination or not. There is now a need to use full-body protective equipment during the expulsive phase, and prenatal care is alternated between face-to-face visits and online appointments. When labor takes long, I sometimes take off my mask to eat and sleep, as I would at the hospital, however, at home, we have a separate space just for us, which is better than the condition in health care institutions, where there is increased risk due to the high transit of people. It was established that birth photographers cannot be present anymore; the accompanying doula must be properly equipped; and the number of companions should be as little as possible, preferably just one. (E1, E2, E4, M2, M4)

\section{SCI 1B - Dealing with frustration}

The collective discourse revealed that changes in the birth planning, required by safety protocols, could impose scenarios different from expected and limit the number of people present at that time, causing frustration to the mother. This reality had to be absorbed by the professionals, who had to face the challenge of devising strategies to deal with this disappointment from the start, in the prenatal appointments.

The planned home birth is very idealized by the woman. They need to adapt not only to a delivery plan, but to a dream. The suspension of the possibility of using the bathtub during labor and delivery brought a lot of frustration. I also had to deal with their disappointment regarding the need to reduce the number of people in the birth scenario, so I had to talk about these necessary changes since prenatal care. In addition, I inform that, if she 
presents suspicious symptoms or confirmation of COVID-19 close to the estimated date of delivery, the birth will have to take place in a hospital instead. (E2, E4, M1, M2, M3)

\section{SCI 1C - Facing the fear of contamination}

Although having access to the necessary equipment to protect themselves from the virus, the discourse showed a constant fear of being contaminated or exposing women under their care to this risk, manifested through feelings of anguish and tension. The contamination of the rest of the team is also of great concern, as that would compromise the care provided to the women assisted by the home birth collective.

The first births almost got me crazy because I wasn't sure how to protect myself. The first time I saw a patient confirmed with COVID-19 was terrible: I remember that, after dressing up, I started to cry. The pressure of the possibility of being contaminated at any moment is huge. I live with the uncertainty that the asymptomatic mother could perhaps be a positive, and after the delivery, I wonder if I got sick and if I could spread the virus. There is also the insecurity of having other infected people inside the birth setting, such as family members and doulas. Any sneezing is a suspicious symptom; this causes me a lot of anguish. Since I'm part of a collective, for me it is also challenging to imagine what would we do if everyone gets sick at the same time. (E1, E3, E4, M1, M2, M4)

\section{SCI 1D - Avoiding exposure to the virus}

Urban midwives bring up in their discourse that, in the home care model, it is difficult to keep distance from the mother, even though they are aware of the risks of exposure to the virus. In addition, there are situations in which labor progresses rapidly and pressures the professionals to skip or hastily dress their protective equipment.

When I realized it, I was already in physical contact with the woman, even though I knew about the risk. In births that progress very quickly, we do not always have time to put on all PPE, or, sometimes, we put them on inadequately, as we cannot leave the woman unassisted. I put myself at risk by prioritizing the care to detriment of wearing the equipment. When the mother is in the expulsive phase, for example, it does not matter how well prepared we are, in this model, the woman has free choice of her position for giving birth, we end up touching her and her fluids. I end up getting dirty from that whole struggle. (E1, E2, M1, M2, M3)

\section{SCI 1E - Keeping distance during the care process}

Based on this discourse, it is evident that establishing a connection with the pregnant woman in PHB care became a challenge in itself in the context of the pandemic, since, in addition to the physical distancing, the professionals needed to deal with the literal barrier imposed by the protection equipment. This reality impaired the relationship between the professional and the mother and got in the way of the team dynamics during the care practice.

My work is completely dependent on physical contact, the relationships in home birth are much closer. It was very difficult to get used to a distanced care, with no hugging, touching, or physically comforting the mother. Having to stop and dress the
Planned home birth assistance: challenges during the COVID-19 pandemic Webler N, Almeida LCG, Carneiro JB, Campos LM, Glaeser TA, Santos MC, et al.

protective equipment when entering the expulsion phase leads to a break of the connection with that moment; sometimes I lose focus of the birth, of that energy. The communication within the team was also compromised by the distancing and use of protective equipment, as, in normal circumstances, we communicate mostly through touching and facial expressions. In addition, the home birth is planned during prenatal care; what used to be a home visit, chatting while having a cup of coffee, now happens at a distance, making bonding with the family more difficult. (E1, E2, E4, M1, M2)

\section{DISCUSSION}

The discourse shows recurrent adaptations in the care practice of urban midwives as one of the challenges brought by the pandemic, revealing changes that have occurred in the practice of prenatal care and in the way the team performs during home labor. In this emergency context, professionals were required to quickly adapt to ensure safe care, even when having to deal with still incipient scientific information about the disease in hospital or home environments. Specifically, regarding obstetric care, new information on virus repercussions in the lives of pregnant women and newborns was constantly disseminated by the international medial during the first months of the pandemic ${ }^{(22-23)}$.

In the Brazilian scenario, the alarming data on the morbidity and mortality of pregnant women raised efforts to safeguard these lives. In this sense, the release of the technical note from the $\mathrm{MH}$, which classified this portion of the population as a risk group for COVID-19, pointed out the importance of greater precaution in the care of mothers during and after pregnancies, and care practices were established to consolidate those changes in the routine of services ${ }^{(24-25)}$. Regardless of the birth care scenario, changes often limit the woman's full autonomy, which also causes frustration for professionals, as they feel that they are not able to provide proper humanized care as they used to.

Given the severity of the virus for the pregnant woman, the interviewed professionals mentioned that, according to the recommendations of the $\mathrm{MH}$, it was necessary to alternate between face-to-face and online appointments to carry out prenatal care. In addition to that, online communication becomes the only option when women exhibit any suspicious symptoms or have had recent contact with someone positive for COVID-19(25). Thus, remote meetings have become a valuable resource to ensure the monitoring of the mothers' and fetus' well-being at a time when physical distancing is necessary, although urban midwives report a weaker bond when comparing to conventional face-to-face visits at home.

Countries such as China and the United States of America also employed online appointments as a tool for monitoring pregnant women during the pandemic period ${ }^{(26-27)}$. Although it is a way to maintain prenatal care, this is not a reality for the entire Brazilian scenario, as some women, users of public or private services, have this right denied, leaving them unattended and endangering the lives of the woman and the fetus(28-30).

In addition to prenatal care, professionals had to update themselves to work within the labor and delivery scenarios, seeking national and international recommendations to develop protocols to safely guide their care practices. In the meantime, although there was no scientific consensus, the evidence pointed 
to the detection of SARS-CoV-2 RNA in blood, urine, and feces samples from contaminated people, being necessary to avoid contact with such bodily fluids due to the risk of contamination $^{(15)}$. Thus, despite the benefits of using water birth as a pain relief technique, this resource became not advisable for mothers in labor ${ }^{(31)}$. Although immersion in water is not recommended, showers should be encouraged, as in addition to promoting relaxation and pain relief for women, it helps with hygiene when necessary ${ }^{(32-33)}$.

Another change adopted to ensure safe care is the restriction of access to the birth scene for people such as photographers, family, and friends, recommending solely the presence of a doula and one companion chosen by the woman. In this regard, it is important to point out that the presence of a doula in the birth scenario leads to a more positive experience, bringing benefits such as better pain control during childbirth, reduced use of analgesics, and a better chance to experience the golden hour ${ }^{(34-35)}$. Therefore, understanding such benefits and considering that these professionals are regulated and prepared to act during the pandemic, the right to have the presence of a doula was ensured in the PHB scenario, even though they are barred from entering maternity hospitals, which represents a setback to women's rights.

Both the restriction on the use of specific techniques and the limitation on the number of people present are new and unusual circumstances for the mother planning her PHB. In general, she is encouraged to play a protagonist role during childbirth through, for example, understanding the physiology of the process and elaborating the birth plan, expressing her wishes and preferences. Therefore, urban midwives needed to talk with the pregnant women, even during prenatal care, about the new scenario of childbirth and the necessary adaptations. This practice is in line with the humanization of care, as it prioritizes respect for the women's informed choices and allows her to participate in the decision-making processes ${ }^{(36-37)}$.

The disappointment in the professionals' speeches is also related to the always present possibility of the woman needing to be transferred to a hospital in an emergency, in case of suspicion or confirmation of COVID-19. This change in scenario is adopted considering the possibility of a rapid decline of the clinical condition of the mother, with repercussions such as an abrupt drop in blood oxygenation, which may require ventilatory support and monitoring in an Intensive Care Unit ${ }^{(38-40)}$. It should be noted that low-risk PHB with the presence of trained professionals is a growing trend, associated with positive outcomes and not linked to higher rates of maternal or fetal morbidity and mortality compared to births in hospitals, thus configuring a positive option for pregnant women ${ }^{(35,41-44)}$.

Even when there is no suspicion of COVID-19, professionals need to deal with the chance of asymptomatic cases, so they feel insecure in the environment, even if they have taken precautionary measures. This is due to the need to remain in the mother's home for long periods, forcing them to share rooms and personal objects, as well as the need to remove their PPE to fulfill physiological needs. Furthermore, the care practice itself implies a risk, as it requires the professional to be in continuous physical contact with the woman. It is important to emphasize that, in the hospital environment, where multiple families are being monitored at the same time, this risk of contamination may be increased as it is an area with constant flow of people ${ }^{(35,45)}$.

In this sense, the fear of contamination generates anxiety in professionals, with manifestations of psychological distress. This anguish was correlated with the risk of having their care services rendered unavailable as a result of widespread contamination within the team, as well as the risk of transmission of the virus to their own family or others under the care of the team. Hence, the use of personal protective equipment (PPE), such as a cap, N-95 mask, face shield, waterproof apron, and disposable shoes, is imperative, being incorporated into the new reality of obstetric care $^{(25)}$. In this regard, it is noteworthy that the removal of protective equipment is a moment with an increased risk of contamination, with guidelines published by the $\mathrm{MH}$ concerning this situation to be strictly followed by health workers ${ }^{(46)}$.

The adequate use of PPE is especially challenging in situations in which labor progresses rapidly, where the midwife may not have time to get properly equipped in order to respond quickly to the needs of the mother. In addition, respecting women's free choice of position in the expulsion phase, for example, can be an element that makes the professional vulnerable to contamination, considering the possibility of contact with fluids. Another factor that also impacts the PHB is the use of masks, perceived by the participants as a factor that distances them from the mother, weakening the connection between them. This is because, in the birth process, a strong bond is established between the pregnant woman and the obstetric nurse, which goes beyond verbal communications, and therefore the use of facial expressions is important ${ }^{(14)}$.

It is also worth noting, as pointed out by the participants, that these newly adopted safety procedures generate external noise in the birth scenario - when the team has to get equipped or use verbal communication. This new reality contrasts with previous practices which tried to be as silent as possible to allow the family interaction and the woman to connect with the moment she is going through ${ }^{(47-48)}$. A comfortable and welcoming space is needed for this moment of intimacy, favoring the woman's relaxation and enhancing her connection with the energy of the moment, which can add quality to care and help in the progression of labor ${ }^{(49)}$.

\section{Study limitations}

Considering that urban midwives working in the PHB scenario establish their own work procedures, the challenges encountered by the care providers may vary according to the region where they work. Thus, the study is limited by not exploring how this care model has been conducted by professionals working in other parts of the country, other than the Brazilian Northeast.

\section{Contributions to Nursing, Health, and Public Policies}

The study contributes to the diffusion of strategies designed to adapt the care provided to women during and after pregnancy in this challenging context, to ensure the safety of everyone involved in the event, and satisfy the premises of humanized care. 
For the obstetric area, these findings are even more relevant, as they contribute to the autonomy and professional safety of nurses and obstetricians working in the PHB scenario, with emphasis on the former, as they are the main provider in this care model.

\section{FINAL CONSIDERATIONS}

The urban midwives' speeches revealed a challenging reality in the care of planned home births in the context of the COVID-19 pandemic, because, in order to offer safe care, valuing the protection of women, companions, and professionals from possible contamination, it is necessary to face the fear of the disease and comply with strict health recommendations, even though these can impact the bond between the mother and the professional and generate struggle for everyone involved.

In a scenario with few official protocols to guide professional practice and limited dissemination of guidelines for conducting PHB care, especially during the pandemic, the study is beneficial by making accessible quality information that can guide professionals to obstetric practices based on scientific evidence and aligned with humanized care values.

\section{ACKNOWLEDGMENT}

We thank the midwives who participated in the study for contributing to the progress of science on planned home birth.

\section{REFERENCES}

1. Cursino TP, Benincasa M. Parto domiciliar planejado no Brasil: uma revisão sistemática nacional. Cienc Saude Colet. 2020;25(4):1433-43. http://doi.org/10.1590/1413-81232020254.13582018

2. Conselho Regional de Enfermagem do Espírito Santo. Hospital público mineiro comemora um ano de parto domiciliar [Internet]. Vitória (ES): Coren/ES; 2015[cited 2021 Jan 20]. Available from: http://www.coren-es.org.br/hospital-publico-mineiro-comemora-um-ano-de-parto-domiciliar_5055.html

3. Sánchez-Redondo MD, Cernada M, Boix H, Espinosa Fernández MG, González-Pacheco N, Martín A, et al. Home births: a growing phenomenon with potential risks. An Pediatr (Barc). 2020;93(4):266.e1-e6. http://doi.org/10.1016/j.anpedi.2020.04.005

4. Cheyney M, Davis-Floyd R. Birth in eight cultures. Long Grove (IL): Waveland Press; 2019. Chapter 1, Birth as culturally marked and shaped; p. 1-16.

5. Ministério da Saúde (BR). Diretrizes nacionais de assistência ao parto normal: versão resumida [Internet]. Brasília, DF: MS; 2017 [cited 2021 Jan 20]. Available from: https://bvsms.saude.gov.br/bvs/publicacoes/diretrizes_nacionais_assistencia_parto_normal.pdf

6. Conselho Regional de Medicina do Rio de Janeiro. Resolução n. 265/12. Dispõe sobre a proibição da participação do médico em partos domiciliares. DOE RJ. 19 Jul 2012;(parte V):10.

7. Conselho Regional de Medicina do Estado de Santa Catarina. Resolução no 193/2019. Dispõe sobre a proibição da participação do médico em partos fora do ambiente hospitalar; dispõe sobre a proibição de adesão [...]. DOE SC. 26 Ago 2019;22.

8. Denipote AGM, Lacerda MR, Nascimento JD, Tonin L. Parto domiciliar planejado no Brasil: onde estamos e para onde vamos? Res Soc Dev. 2020;9(8):e837986628. http://doi.org/10.33448/rsd-v9i8.6628

9. Conselho Federal de Enfermagem (BR). Parecer Técnico CNSM/COFEN nº 003/2019. Parecer Técnico para alinhamento da "regulação e prática da enfermagem obstétrica no espaço do parto domiciliar planejado", conforme designação da Portaria COFEN no 1092 de 17 de 2019 [Internet]. Brasília, DF: COFEN; 14 Aug 2019[cited 2021 Jan 19]. Available from: http://www.cofen.gov.br/wp-content/uploads/2019/10/ PARECER-T\%C3\%89CNICO-CNSM-COFEN-N\%C2\%BA-003-2019.pdf

10. Conselho Regional de Enfermagem de São Paulo. Parecer COREN-SP GAB no 012/2011. Parto domiciliar [Internet]. São Paulo: COREN/SP; 11 Mar 2011[cited 2021 Jan 19]. Available from: https://portal.coren-sp.gov.br/wp-content/uploads/2013/07/parecer_coren_sp_2011_12.pdf

11. Conselho Regional de Enfermagem da Bahia. Parecer COREN-BA n॰ 023/2015. Atendimento domiciliar pelo enfermeiro obstetra (pré-natal, parto e puerpério) [Internet]. Salvador (BA); 27 Nov 2015[cited 2021 Jan 19]. Available from: http://ba.corens.portalcofen.gov.br/wpcontent/uploads/2016/06/PT-023-ATENDIMENTO-DOMICILIAR-PELO-ENFERMEIRO-OBSTETRA.pdf

12. Conselho Regional de Enfermagem de Santa Catarina. Parecer Técnico COREN/SC n 023/CT/2016. Parto Domiciliar Planejado [Internet]. Florianópolis (SC): COREN/SC; 14 Dec 2016[cited 2021 Jan 20]. Available from: http://www.corensc.gov.br/wp-content/uploads/2017/01/ PT-023-2016-Parto-Domiciliar-Planejado.pdf

13. Koettker JG, Bruggemann OM, Freitas PF, Riesco MLG, Costa R. Obstetric practices in planned home births assisted in Brazil. Rev Esc Enferm USP. 2018;52:e03371. http://doi.org/10.1590/S1980-220X2017034003371

14. Oliveira PS, Couto TM, Gomes NP, Campos LM, Lima KTRS, Barral FE. Best practices in the delivery process: conceptions from nurse midwives. Rev Bras Enferm. 2019;72(2):455-62. http://doi.org/10.1590/0034-7167-2018-0477

15. World Health Organization. Transmission of SARS-CoV-2: implications for infection prevention precautions [Internet]. Geneva:WHO; 9 Jul 2020[cited 2021 Jan 20]. Available from: https://www.who.int/news-room/commentaries/detail/ transmission-of-sars-cov-2-implications-for-infection-prevention-precautions

16. Nakamura-Pereira M, Andreucci CB, Menezes MO, Knobel R, Takemoto MLS. Worldwide maternal deaths due to COVID-19: a brief review. Int J Gynaecol Obstet. 2020;151(1):148-50. http://doi.org/10.1002/ijgo.13328

17. Takemoto MLS, Menezes MO, Andreucci CB, Knobel R, Sousa LAR, Katz L, et al. Maternal mortality and COVID-19. J Matern Fetal Neonatal Med. 2020. http://doi.org/10.1080/14767058.2020.1786056 
18. Ministério da Saúde (BR). Doença pelo coronavírus: 2019. Bol Epidemiol [Internet]. 3 Apr 2020[cited 2021 Jan 20];(6):1-23.Available from: https://portalarquivos.saude.gov.br/images/pdf/2020/April/03/BE6-Boletim-Especial-do-COE.pdf

19. Lefevre F, Lefevre AMC, Marques MCC. Discurso do Sujeito Coletivo, complexidade e auto-organização. Cienc Saude Colet. 2009;14(4):1193204. http://doi.org/10.1590/S1413-81232009000400025

20. Lefevre F, Lefevre AMC. Pesquisa de representação social: um enfoque qualiquantitativo: metodologia do discurso do sujeito coletivo. Brasília, DF: Liber Livro; 2010.

21. Dall'Agnol CM, Magalhães AMM, Mano GCM, Olschowsky A, Silva FP. A noção de tarefa nos grupos focais. Rev Gaucha Enferm. 2012;33(1):186-90. http://doi.org/10.1590/S1983-14472012000100024

22. Melo GC, Araújo KCGM. COVID-19 infection in pregnant women, preterm delivery, birth weight, and vertical transmission: a systematic review and meta-analysis. Cad Saude Publica. 2020;36(7):e00087320. http://doi.org/10.1590/0102-311x00087320

23. Tripathi S, Gogia A, Kakar A. COVID-19 in pregnancy: a review. J Family Med Prim Care. 2020;9(9):4536-40. http://doi.org/10.4103/jfmpc. jfmpc_714_20

24. Ministério da Saúde (BR). Nota Técnica no 13/2020, COSMU/CGCIVI/DAPES/SAPS/MS. Recomendações acerca da atenção puerperal, alta segura e contracepção durante a pandemia da COVID-19. Brasília, DF; 2020[cited 2021 Jan 20]. Available from: https://portaldeboaspraticas. iff.fiocruz.br/biblioteca/nota-tecnica-no-13-2020-cosmu-cgcivi-dapes-saps-ms/

25. Ministério da Saúde (BR). Manual de recomendações para a assistência à gestante e puérpera frente à pandemia de covid-19 [Internet]. Brasília, DF: MS; 2020[cited 2021 Jan 21]. Available from: http://189.28.128.100/dab/docs/portaldab/documentos/corona/manual_ recomendacoes_gestantes_covid19.pdf

26. Wu H, Sun W, Huang X, Yu S, Wang H, Bi X, et al. Online antenatal care during the covid-19 pandemic: opportunities and challenges. J Med Internet Res. 2020;22(7):e19916. http://doi.org/10.2196/19916

27. Aziz A, Zork N, Aubey JJ, Baptiste CD, D'Alton ME, Emeruwa UN, et al. Telehealth for high-risk pregnancies in the setting of the covid-19 pandemic. Am J Perinatol. 2020;37(8):800-8. http://doi.org/10.1055/s-0040-1712121

28. Ribeiro T. Mulheres grávidas encontram dificuldades para realizar pré-natal em SP. Agora São Paulo [Internet]. 8 Apr 2020 [cited 2021 Jan 20]. Available from: https://agora.folha.uol.com.br/sao-paulo/2020/04/mulheres-gravidas-encontram-dificuldades-para-realizar-pre-natalem-sp.shtml

29. Lobato $D$. Em meio à pandemia, grávidas e puérperas vivem dificuldades com atendimento nas periferias [Internet]. São Paulo: Agência Mural; 2020[cited 2021 Jan 21]. Available from: https://www.agenciamural.org.br/ em-meio-a-pandemia-gravidas-e-puerperas-vivem-dificuldades-com-atendimento-nas-periferias/

30. Sieglitz A. Gravidez e covid-19: dia da gestante alerta sobre a importância dos cuidados durante a pandemia [Internet]. Minas Gerais: Fundação Hospitalar do Estado de Minas Gerais; 14 Aug 2020[cited 2021 Jan 21]. Available from: http://www.fhemig.mg.gov.br/sala-deimprensa/noticias-sala-imprensa/1934-gravidez-e-covid-19-dia-da-gestante-levanta-discussoes-sobre-a-importancia-dos-cuidadosdurante-a-pandemia

31. Ministério da Saúde (BR). Nota Técnica n 9/2020, COSMU/CGCIVI/DAPES/SAPS/MS. Recomendações para o trabalho de parto, parto e puerpério durante a pandemia da covid-19. Brasília, DF: MS; 2020.

32. Royal College of Obstetricians and Gynaecologists. Coronavirus (COVID-19) infection in pregnancy: information for healthcare professionals [Internet]. London: RCOG; 2020[cited 2021 Jan 20]. Available from: https://www.rcog.org.uk/globalassets/documents/guidelines/2020-1014-coronavirus-covid-19-infection-in-pregnancy-v12.pdf

33. Federação Brasileira das Associações de Ginecologia e Obstetrícia. Protocolo de atendimento no parto, puerpério e abortamento durante a pandemia da covid-19 [Internet]. São Paulo: FEBRASGO; 2020[cited 2021 Jan 21]. Available from: https://www.febrasgo.org.br/en/covid19/ item/1028-protocolo-de-atendimento-no-parto-puerperio-e-abortamento-durante-a-pandemia-da-covid-19

34. Hans SL, Edwards RC, Zhang Y. Randomized controlled trial of doula-home-visiting services: impact on maternal and infant health. Matern Child Health J. 2018;22(suppl 1):105-13. https://doi.org/10.1007/s10995-018-2537-7

35. Davis-Floyd R, Gutschow K, Schwartz DA. Pregnancy, birth and the COVID-19 Pandemic in the United States. Med Anthropol. 2020;39(5):41327. https://doi.org/10.1080/01459740.2020.1761804

36. Sodré TM, Merighi MAB. Escolha informada no parto: um pensar para o cuidado centrado nas necessidades da mulher. Cienc Cuid Saude. 2012;11(5):115-20. https://doi.org/10.4025/cienccuidsaude.v11i5.17062

37. Martins APC, Jesus MVN, Prado Jr PP, Passos CM. Aspects influencing women's decision making about the mode of delivery. Rev Baiana Enferm. 2018;32:e25025. https://doi.org/10.18471/rbe.v32.25025

38. Poon LC, Yang H, Dumont S, Lee JCS, Copel JA, Danneels L, et al. ISUOG interim guidance on coronavirus disease 2019 (covid-19) during pregnancy and puerperium: information for healthcare professionals, an update. Ultrasound Obstet Gynecol. 2020;55(6):848-62. https://doi. org/10.1002/uog.22061

39. Rasmussen SA, Smulian JC, Lednicky JA, Wen TS, Jamieson DJ. Coronavirus disease 2019 (covid-19) and pregnancy: what obstetricians need to know. Am J Obstet Gynecol. 2020;222(5):415-26. https://doi.org/10.1016/j.ajog.2020.02.017

40. Hantoushzadeh S, Shamshirsaz AA, Aleyasin A, Seferovic MD, Aski SK, Arian SE, et al. Maternal death due to covid-19. Am J Obstet Gynecol. 2020;223(1):109.e1-16. https://doi.org/10.1016/j.ajog.2020.04.030 
41. Cheyney M, Bovbjerg M, Everson C, Gordon W, Hannibal D, Vedam S. Outcomes of care for 16,924 planned home births in the United States: the Midwives Alliance of North America statistics project, 2004 to 2009. J Midwifery Womens Health. 2014;59(1):17-27. https://doi. org/10.1111/jmwh.12172

42. Reitsma A, Simioni J, Brunton G, Kaufman K, Hutton EK. Maternal outcomes and birth interventions among women who begin labour intending to give birth at home compared to women of low obstetrical risk who intend to give birth in hospital: a systematic review and meta-analyses. EClinicalMedicine. 2020;21:100319. https://doi.org/10.1016/j.eclinm.2020.100319

43. Jonge A, Geerts CC, van der Goes BY, Mol BW, Buitendijk SE, Nijhuis JG. Perinatal mortality and morbidity up to 28 days after birth among 743070 low-risk planned home and hospital births: a cohort study based on three merged national perinatal databases. BJOG. 2015;122(5):720-8. https://doi.org/10.1111/1471-0528.13084

44. MacDorman MF, Declercq E. Trends and state variations in out-of-hospital births in the United States, 2004-2017. Birth. 2019;46(2):279-88. https://doi.org/10.1111/birt.12411

45. Liu Y, Ning Z, Chen Y, Guo M, Liu Y, Gali NK, et al. Aerodynamic analysis of SARS-CoV-2 in two Wuhan hospitals. Nature. 2020;582(7813):55760. https://doi.org/10.1038/s41586-020-2271-3

46. Ministério da Saúde (BR). Sequência correta na paramentação dos profissionais de saúde [Internet]. Brasília, DF: MS; 2020[cited 2021 Jan 20]. Available from: https://www.sbac.org.br/wp-content/uploads/2020/05/Sequ\%C3\%AAncia-correta-na-paramenta\%C3\%A7\%C3\%A3o-dosprofissionais-de-sa\%C3\%BAde.pdf

47. Odent M. O Camponês e a parteira: uma alternativa à industrialização da agricultura e do parto. São Paulo: Ground; 2003.

48. Leboyer F. Nascer sorrindo. São Paulo: Brasiliense; 1994.

49. Sousa FLP. Formação em humanização do parto e nascimento [Internet]. São Paulo: Fundação Maria Cecilia Souto Vidigal; 2014 [cited 2021 Jan 22]. Available from: http://agendaprimeirainfancia.org.br/arquivos/caderno_07_web_cor.pdf 